\title{
EDITORIAL
}

\section{TAKING A STRATEGIC VIEW}

\section{Sulina Green}

This special issue of Social Work/Maatskaplike Werk appears on the eve of the $34^{\text {th }}$ Congress of the International Association of Schools of Social Work (IASSW) to be held in Durban, South Africa next month. As the main theme of the Congress is Transcending Global-Local Divides: Challenges for Social Work Education and Practice, this issue is intended to expose our readers to strategic thinking about social welfare issues with articles by some of the conferees as well as prominent researchers and practitioners in South Africa. The special issue introduces researchers' responses to challenges for social work during a period of socio-economic transformation.

In setting strategic direction for social welfare, the South African government has adopted a developmental social welfare approach to social service provision. This is in line with the Constitution (Act No 108 of 1996), the Reconstruction and Development Programme (African National Congress, 1994) and the White Paper for Social Welfare (Ministry for Welfare and Population Development, 1997). This approach included a focus on the social and economic development of individuals and families in their communities. A decade later this approach to social welfare was also aligned with the Integrated Service Delivery Model (Department of Social Development, 2006). This model incorporates community awareness and prevention, early intervention, statutory intervention and alternative care arrangements for those with special needs.

The introduction of this model happened at a time when the social development sector was faced with enormous social challenges resulting from structural poverty, unemployment, inequality and other social ills such as HIV and AIDS associated with such phenomena. The Integrated Social Services Delivery Model (1996) has challenged us to adopt a different approach to service delivery if we are to meet the needs of the poor and vulnerable. This applies both to the Government and to the Non Governmental Organisations in the field of social welfare. To meet these challenges it is essential to build partnerships that develop joint innovative solutions for sustainable development.

Although this issue acknowledges progress in the practice and implementation of developmental social welfare over the past 11 years, its main purpose is to asks readers to consider some of the major current issues that confront the profession and the present-day role that social work and social service professionals have in services to the poor and vulnerable in society. The informative and thought-provoking articles selected for this issue correspond with some of the sub-themes of the Congress: inequality and poverty, field practice education, child, youth and family centred work, older persons, health, HIV/AIDS and social development.

Vivienne Bozalek and her co-author, Wesley Lambert at the University of the Western Cape share users' experiences of service delivery during a period of socio-economic transformation in their article Interpreting users' experiences of service delivery in the Western Cape using a normative framework. From Antoinette Lombard at the University of Pretoria comes the thoughtful article Social work: A social partner in economic development. This article builds a compelling case for a developmental social welfare policy shift to a sustainable livelihood approach to position social work as a social partner contributing to the achievement of national social development goals. Next we have two timely articles about the care of children. Roseline September provides the reader with a factual and extensive exposition of the long awaited New Children's Act in her article A new Children's Act for South Africa: Making it work for children and families. The author highlights the centrality of the objectives and values inherent in the 
legislation and discusses issues and obstacles that may impede the implementation of the Act. Nevashnee Perumal and Madhu Kasiram at the University of KwaZulu Natal in their article Children's homes and foster care: Challenging dominant discourses in South African social work practice address key concerns surrounding dominant views of foster care being the best alternative care option for vulnerable children in South Africa.

The spectre of unemployment, which is a reality for social work practitioners in South Africa, is the subject of the article by Herman Strydom and Alida Herbst at the University of the NorthWest in the article The psychosocial implications of the closing of a mine for workers and their families. Using systems theory as theoretical framework Sue Parton and Sulina Green at the Stellenbosch University offer the article A comparison of subjective quality-of-life indicators across domains of Jewish seniors living in the community. Finally Mike Weyers and Herman Strydom at the University of the North-West and co-author Arnel Huisamen describe in their article Triangulation in social work research: the theory and examples of its practical application a research project undertaken by Police Social Work Services that dealt with testing the effect of an HIV/AIDS awareness programme.

It is our sincere editorial hope that some of the crucial issues raised and pursued here might further the debate embodied in the upcoming conference in Durban.

\section{REFERENCES}

AFRICAN NATIONAL CONGRESS (ANC). 1994. The Reconstruction and Development Programme. A Policy Framework. Johannesburg: Umamyano Publishers.

DEPARTMENT OF SOCIAL DEVELOPMENT. 2006. Integrated Service Delivery Model towards improved social services. Pretoria: Government Printers.

MINISTRY FOR WELFARE AND POPULATION DEVELOPMENT. 1997. White Paper for Social Welfare. Pretoria: Government Printers. 